\title{
Introduction: The Cynics, Optimists and Pirates are all Making Africa Beautiful
}

\author{
CHARLES ONYANGO-OBBO
}

There are two dominant positions about Africa today and in the near future: on the one side, a heady optimism that envisions 'Africa Rising', and on the other a cynicism that sees a continent still trapped in 'darkness'. In between you find the simply weary, mildly celebratory, and nearly indifferent.

The majority of articles in this issue hug the vast middle; there is shy pessimism, cautious optimism, but also recognition that Africa's development has not and probably will not be linear, and interesting possibilities could - or might not-emerge as nations muddle along. And even where outcomes have been disastrous, and nations starved and people killed or oppressed, there is some acknowledgement that most of Africa's Big Men (it has been men for the most part) set out with good intentions.

Together, this search for new vantage points to evaluate the continent, the recognition that enough of 'old Africa' still persists to justify pessimism, but also that optimism about the continent has not been snuffed out by the failures and disappointments of recent decades, is beautiful to see. This is because these various outlooks prevent a slide into the complacency and insularity that are often born of an overblown sense of achievement, or the despair that can be bred by pessimism.

The common thread among nearly all the authors, and increasingly in most discussions about current events in Africa, is that there is no hard and fast formula to predict outcomes. Thus, Elsie Eyakuze's notions of feminism were not formed through a fortuitous encounter with Gloria Steinem, but from the revulsion of going to early school in highly patriarchal Swaziland, and witnessing the country suffering under the absolute rule of polygamous and profligate King Mswati III.

Then, in December 2007 there was a disputed election in Kenya. Over 1,000 people were killed and nearly 600,000 displaced in the bout of post-election violence that followed in early 2008. That violence also produced Kenya first large group of refugees, with 6,000 of them fleeing to Uganda.

It was the worst violence in Kenya since independence in 1963, and the country's lowest moment of the last 50 years. However, as it turned out, it was perhaps also the shock that Kenya needed, and the event that unlocked the creativity in new technology

Development (2012) 55(4), 435-440. doi:10.1057/dev.2012.87 
that earned the country the moniker 'Silicon Savannah, and led to its most far-reaching political reforms.

As Elsie Kanza notes, Ushahidi, a free online crisis-mapping platform, was created during the post-election period in Kenya to track and map incidents of violence and peace efforts. Ushahidi (Kiswahili for 'Witness') has since become one of the most successful exports out of Africa. Last year co-founder Juliana Rotich told TIME magazine that, after its founding, 'Ushahidi quickly became the world's default platform for mapping crises, disasters and political upheaval' (Perry, 2011). By May of 2011, it had been used 14,000 times in 128 countries to map everything from the 2010 earthquake in Haiti, the 2011 Japanese tsunami and the Arab Spring (Perry, 2011).

Ushahidi is a social good product. The big money maker has been M-Pesa ( $\mathrm{M}$ for mobile, Pesa is Swahili for money), a mobile phone-based money transfer and micro-financing service created by the Kenyan mobile phone company Safaricom. Currently, it is the most developed mobile payment system in the world. ${ }^{1}$ M-Pesa also helped overcome the criticism that so many of the digital innovations in Africa today are mostly feel-good, technology-for-technologies creations, which do not put food on the table.

On 9 October 2012, in its quarterly update, the Communications Commission of Kenya (CCK), the industry regulator, reported that Kenyans deposited US\$ 8 billion in M-Pesa and other mobile money services for the year ending June 2012 - a 38 percent rise over the same period in 2011. But perhaps more important was the number of people employed in the M-Pesa business. CCK reported that the number of mobile money agents rose 16 percent to 49,079 while the number of mobile money subscriptions rose by 12.13 percent to reach 19.5 million $^{2}$ in a country with a population of 42 million.

Thus apart from the jobs, M-Pesa has offered over 12 million people banking services because by comparison 6.4 million Kenyans had regular bank accounts at the last count. ${ }^{3}$

Quite a few people are alive to the ironies of this. In September 2012, at end of the UN's Social Good 436 Summit in Nairobi, we were milling around the coffee table. There had been many presentations on interesting technology innovations in music, conservation, humanitarian work, and online gaming.

As he poured out his coffee, a disgruntled techie remarked - as a criticism - that the technologies Kenya was famous for in the world were born out of 'poverty' (M-Pesa thrived because the traditional banks did not bother with low-earning workers and rural folks), and 'violence' (Ushahidi). Yet the point could also be made that there is something salutary to be said for these kinds of responses to crisis and adversity. Indeed, one of the boosts that sent M-Pesa growing like wild fire was provided by the post-election violence.

Because many people could not travel to see their families, as roads had been closed by machete-wielding gangs, or drivers were simply too terrified to put their buses and taxis on the highways, the only method available to send money from the city to upcountry was M-Pesa. That gave the platform social legitimacy.

M-Pesa, it can be said, unwittingly turned out to be a formidable soldier in Kenya's gender wars. Some estimates have it that up to 600,000 women who would not have got anywhere near a bank because of the strictures of patriarchy now have M-Pesa accounts.

Separately, while the violence scarred Kenya, it also opened the door for the adoption of a new constitution in August 2010, one of the most progressive such laws in Africa. The struggle for a new constitution had been going in the country for 25 years up to that point, but had been defeated by anti-reformist forces for that long.

These trends of technology opening doors that had been closed by tradition, hobbled by bureaucracy, or stifled by mercantilist small-mindedness, are evident all over Africa.

In many countries in Africa you will see a Coca Cola TV advert, which, in proclaiming the continent's promise, says that the number of films (the quality notwithstanding) made in Africa a year are more than what Hollywood and the Indian film industry, Bollywood, produce over the same period.

Most of these African films are produced by Nollywood, Nigeria's film industry. They are now 


\section{Onyango-Obbo: Introduction}

all the rage on the continent. A few years ago, the main pay TV company in Africa, South Africa's Multichoice, did not carry any Nollywood films. Today, it has eight channels dedicated to Nollywood and other Nollywood-inspired films from several African countries. The now wealthy Nollywood impresarios did not plan this - it was the Internet and criminals - especially smugglers and pirates - who brought them the boon.

In December 2010, The Economist had a fascinating account of how pirates and smugglers turned Nollywood into a continental phenomenon.

As soon as a [Nollywood] film is released, copyright thieves rip it off. It takes the pirates just two weeks to copy a new film and distribute it across Africa. The merchants must take their money during that fortnight, known as the "mating season", before their discs become commodities. As soon as the mating season is over they start thinking about the next film, ${ }^{4}$

'The merchants curse the pirates, but in a way they are a blessing. Pirate gangs were probably Nollywood's first exporters. They knew how to crosstricky borders and distribute goods across a disparate continent where vast tracts of land are inaccessible. Sometimes they filled empty bags with films when returning from an arms delivery. Often they used films to bribe bored guards at remote borders ... The pirates created the panAfrican market."

So it seems Nigerian filmmakers might also have found a possible solution to the growing problem of international piracy of films, TV series, and maybe even music: countries should adopt their own versions of 'mating seasons'.

The Internet too has enabled the distribution of Nollywood films, and broken down borders for businesses that were inconceivable ten years ago.

One of South Africa's 'quietest' tech success stories is a seven-person business that has gone from startup to profitability in just four years - without ever marketing itself or taking a cent of outside financing.

'In the process, mobile social network 2 go has come to dominate the Nigerian market, where it has over nine million active users - several million more than Facebook, the company claims. ${ }^{5}$
$2 g o$ is a mobile social network targeting users in emerging markets, particularly in Africa. The company has over 21 million registered users with more than 10 million active users in Nigeria, South Africa, and Kenya. User adoption is growing rapidly at approximately 50,000 new registrations a day. ${ }^{5}$

Not only is the Internet providing new channels of distribution and enabling new winners to emerge, but also globally it is allowing the stardust from the success of African companies to rub off on others. A Kenyan company Craft Silicon, one of the fastest growing financial software companies in Africa, is now exporting to Latin America and Europe after winning contracts with over 200 financial institutions in 40 countries across Africa and Asia.

The knock-on effects of these stirrings on the continent are also beginning to be seen in education, one of the most conservative and reformresistant sectors in Africa.

For example, Strathmore University in Kenya, one of East Africa's leading private universities, is pioneering Africa's first Centre for Research in Energy and Energy Conservation, modelled on a similar initiative in Brazil that saw the country increase its use of ethanol instead of petrol to 99 percent.

In Ghana, the Kwame Nkrumah University of Science and Technology is using grid computing for energy research in the fields of petroleum and renewable energy.

We would have liked, and we did not get to explore more of these developments in length, in this issue. However, one of my biggest regrets is that we did nothing about the impact of the African Diaspora on the continent.

In March 2011, a joint report by the African Development Bank and The World Bank estimated that there were about 30 million Africans living outside their home countries, ${ }^{6}$ with about 10 million in Europe, North America, Asia, and the Middle East.

The report, Leveraging Migration for Africa: Remittances, Skills, and Investments, found evidence that suggest migration and remittances reduce poverty in the origin communities and lead to increased investments in health, education, and 
housing in Africa. Diasporas also provide capital, trade, knowledge, and technology transfers. ${ }^{6}$

This role of the Diaspora has been well documented. Lately, the World Bank has also noted that sub-Saharan African countries can potentially raise \$5-\$10 billion a year in Diaspora bonds.

What is only beginning to be explored are the subtle and in some cases very overt ways in which the Diaspora is influencing policy and structural shifts on the continent. How this plays out will have a lot of bearing on some of the changes that will happen in Africa in the years to come.

One of the first countries in Africa where the Diaspora factor affected policy choices considerably was Rwanda. As a result of the 1950s' and 1960s' 'revolutions', expulsions, and the 1990s' war, a significant Rwandese Diaspora (many refugees and exiles) developed over the years.

The Rwanda Ministry of Foreign Affairs estimates that six million people of 'Rwandese descent' live abroad, mainly in other East African countries, Western Europe, and North America. This number is over half the entire population of eleven million people living in Rwanda.

The ruling Rwanda Patriotic Front (RPF), partly because of its roots as an exile guerrilla movement, reserves nearly 30 percent of the seats at its annual congresses for the Rwandese Diaspora. Rwanda was also one of the first countries in Africa to adopt dual citizenship.

Many ministers, senior bureaucrats, and presidential advisers have been Rwandese who returned home on sabbatical for a few years, then went back to countries in Europe and North America where they were also citizens when they were done. The Rwandese government is sometimes criticized for its democracy 'deficit'. However, among the areas in which it is among the top leaders in Africa is that it has one of the continents least corrupt governments, and far one of the most orderly and cleanest cities in most of sub-Sahara Africa, to name a few.

Several commentators in East Africa, and indeed Rwanda itself, have argued that the appointment of many Rwandese from abroad brought into the government system superior skills that were not available domestically. Second, 438 and perhaps most importantly, the knowledge that if a government minister or official is fired, he can return to his university job in Canada, for example, means he is less likely to suck up and accept flawed policies just to protect his job, the way a 'local' who has no such alternatives would do. The evidence for this is still anecdotal, but Rwanda's partners in the East African Community, such as Uganda and Kenya, seem to have been persuaded by the benefits of dual citizenship, and they too have all since adopted in their constitutions.

They are among a growing number of African countries taking the dual citizenship route as a way to engage their Diaspora communities. Some early developments to cope with this new realty can be seen. Apart from a quota for the Diaspora at the ruling RPF congresses, and hiring several of them to work in government, the Rwanda Foreign Ministry established the Diaspora General Directorate.

In turn, among several initiatives, the Rwanda Diaspora Global Network established an annual investment fund that targets to raise \$1.4 million every month to invest in development projects back home.

The Commercial Bank of Rwanda now offers a 'Diaspora Banking Service' and a 'Diaspora Mortgage Facility'.

The Liberian Diaspora fund leverages remittances to seed small and medium size businesses in Liberia. The fund is growing into an influential investment institution in the country.

The Zimbabwe Diaspora Scholarship Fund takes a different tack and provides financial support to talented but economically disadvantaged students to develop the next generation of professionals in Zimbabwe.

These approaches are likely to make a bigger difference in the long-term, because overall most Diaspora remittances still go to funding consumption, whose overall knock-on effects on the economies of various African countries is not as significant as they can be.

The greater reforms that are yet to come are those that will give greater confidence to nationals in country with money to spend it more productively.

A recent illustration of this came in a Bloomberg report. It quoted Mark Mobius, executive 


\section{Onyango-Obbo: Introduction}

Chairman of Templeton Emerging Markets Group speaking in London, saying that Nigerian billionaire Aliko Dangote, Africa's richest man, was by no means as lonely in the club as it might seem. Mobius claimed that there might be as many as 200 'hidden' billionaires operating in the unofficial economy in various African countries.

'You hear about Dangote but there are maybe 200 with the same kind of resources that we do not see. The [underground] economy is very big ... What we see is that these very wealthy people will begin to want to legitimise their wealth by a listing, by putting these assets together, forming a company, listing it', Mobius said. ' Many of these people escaped to London or other countries in order to preserve their wealth. But it is going to get more and more difficult because of antibribery and all the rest that is going on in the US and other parts of the world. ${ }^{7}$

Mobius is wrong in the latter part of his argument. The Africans who flee Africa with their wealth are the ones who got it corruptly. That group does not bring their money back once it becomes difficult to keep it in Swiss and other European and North American banks. They take it further afield to Asia and Latin America. The world is not yet about to run out of havens for hot money. The 'billionaires' who make their money honestly in the parallel economies in various African countries are primarily concerned with keeping it out of the hands of extractive political and state elites who can capture it through forced contributions to election campaigns, extortions, high taxes, and corruption.

These rich Africans mostly want to avoid the formal banking systems, and keep their money in mattresses (figuratively), and assets that are not taxed, such as low-cost housing and real estate, or are completely off the radar such as loan shark operations. In many African countries, most small and medium businesses get their loans from loan shark operators, not international banks whose paperwork and collateral requirements are virtually impossible for them to meet.

The legal, governance, and property rights regimes that will inspire a sufficient number of the African Diaspora, 'hidden' billionaires, and the thousands, if not millions, who are keeping their money in mattresses, ultimately have to happen in a context of improved political leadership and entrenchment of democracy (whichever varieties of it work best for various countries).

However, on current form the prospects for that look dismal. A major setback happened recently when the Mo Ibrahim Foundation announced, as it did in 2009 and 2010, that it did not find a winner for its \$5 Million prize for good governance in Africa.

Not everyone was downcast. Harvard professor Calestous Juma, who co-chairs the African Union's High Level Panel on Science, Technology and Innovation, wrote that while it is important for the Mo Ibrahim Foundation to set very high standards for African leaders, nevertheless the interesting developments in the continent's leadership were happening in areas that the foundation was not catching.

Juma argued in an article in Forbes that it 'appears that the road to democracy is being bridged by a rising technocracy ... While the Mo Ibrahim Foundation was announcing the "no winner", in London, the African Union was installing a South African medic, Dr Nkosazana Dlamini-Zuma, as its new chairperson in Addis Ababa. In 2012 alone, Angola, Egypt, Ethiopia, Senegal,Tunisia and Senegal elected engineers to top political offices. Eritrea and Nigeria are headed by an engineer and a fisheries scientist, respectively'.

Juma noted that 'technical aspirations among African leaders have at times been truly inspirational. When the founding father of Namibia, Sam Nujoma, stepped down from the presidency in 2005, he registered for a Masters programme in geology at the country's national university. He graduated in 2009'.

At that point, only three African presidents had technical training. Today, the number stands at eight. In addition, nearly 40 percent of Egypt's cabinet is made up of engineers. ${ }^{8}$

So what is the value of all this? Juma argued that the change in the technical background of African leaders may appear random, but it represents a significant realignment of Africa's top positions with the continent's contemporary development challenges. Infrastructure concerns 


\section{Development 55(4): Upfront}

(energy, transportation, irrigation, and telecommunications) as well as health tend to dominate local political platforms'.

In 2010, Nation Media Group brought similar thinking to the gamut of indices that measure Africa, and the rest of world. We got the Transparency Corruption Perception Index, the Mo Ibrahim Index, the UNDP Human Development Report, the Economist Intelligence Unit's Democracy Index, Freedom House's Freedom Index, and several others on press freedom and Internet freedom. We brought them together, extracted an Africa ranking, and pulled in other data on other factors such as achievements in immunization, health, nutrition, investments in infrastructure, improvements in agriculture, and also weighted them highly. The result was very different than any of the other indices. Many countries that were near the bottom because of democracy issues, such as Ethiopia, jumped to the top ten. It was quite good; a decision was taken to publish it. It generated so much debate on the Internet, Nation Media Group decided to establish it as an annual Africa Leadership Scorecard. ${ }^{9}$

It was still controversial, and criticized, but it generated a different kind of debate. Thus, when Gabon's President Ben Ali Bongo felt his performance had not been scored fairly, he got his political assistant to write in with a well-argued and unusually methodical product from an African president's State House.

'Be ready to be surprised', would be an appropriate motto for contemporary Africa. And by surprised', you could be elated or heartbroken.

\section{Notes}

1 Wikipedia, http://en.wikipedia.org/wiki/M-Pesa.

2 CCK, 'Internet access and usage increases in the country', 9 October 2012, http://www.cck.go.ke/news/2012/ Internet.access.html.

3 Eric Ombok 'Kenya Bank Accounts Triple to 6.4 Million as Lenders Cut Fees', 25 May 2009, http://www .bloomberg.com/apps/news? pid $=$ newsarchive\&sid $=$ aWjqnCRC39w0\&refer $=$ africa.

4 'Lights, camera, Africa: Movies are uniting a disparate continent, and dividing it too', http://www.economist .com/node/17723124.

5 Sheere Hanna 'South African mobile app is sweeping up', http://www.africanbusinessreview.co.za/technology/ SOUTH-AFRICAN-MOBILE-APP-IS-SWEEPING-UP.

6 'Leveraging Migration for Africa: Remittances, Skills, and Investments', http://siteresources.worldbank.org/ EXTDECPROSPECTS/Resources/476882-1157133580628/AfricaStudyEntireBook.pdf.

7 Lyubov Pronina 'Africa May Have Up To 200 Hidden Billionaires, Mobius Says', 26 September 2012, http:// www.bloomberg.com/news/2012-09-26/africa-may-have-up-to-200-hidden-billionaires-mobius-says-1-.html.

8 Calestous Juma ‘Africa’s Leadership Fails Billionaire Mo Ibrahim’s Test, But Technocrats Rise', 15 October 2012, http://www.forbes.com/sites/mfonobongnsehe/2012/10/15/africas-leadership-fails-billionaire-mo-ibrahims-testbut-technocrats-rise/.

9 Samantha Spooner 'Africa 2011 Leadership Scorecard', http://www.africareview.com/Special+Reports/-/979182/ 1320818/-/ys8u5sz/-/index.html.

\section{References}

Perry, Alex (2011) 'Silicon Savanna: Mobile Phones Transform Africa', 30 June, TIME, http://www.time.com/time/ magazine/article/0,9171,2080702,00.html, accessed 30 October 2012. 